\title{
The organization of organizational discourse ${ }^{1}$
}

\section{Review Essay}

Craig Prichard

Massey University, Aotearoa/NZ

\section{Review Essay}

Renata Fox and John Fox

Organizational Discourse: A Language-Ideology-Power Perspective

Westport, Connecticut, USA: Praeger, 2004, 221 p. ISBN 1567206050 (Hdbk.)

Susanne Tietze, Laurie Cohen and Gill Musson

Understanding Organizations through Language

London, UK: Sage, 2003 , 191 p, ISBN 0761967184 (Pbk.)

\section{Introduction}

\footnotetext{
${ }^{11}$ The author would like to acknowledge MCQ reviews and forum editor Kathleen Krone for her encouragement, helpful support and comments during the preparation of this essay.
} 
'Discourse', as Norman Fairclough and his co-editors noted in the introduction to their new journal, Critical Discourse Studies, (2004), is now well established as category in social sciences. And yet, as they also note, there are significant differences as to what 'discourse' and 'discourse analysis' refers. These differences are, they argue, due to different theoretical, academic and cultural traditions and how they 'push discourse in different directions' (2004:4). In this review essay I sketch out the key direction that 'discourse' has been pushed or pulled in organization studies (see also Alvesson and Karreman, 2000; Chia, 2000; Grant et al, 2004; Fairhurst and Putnam, 2004; Prichard et al, 2004). To set the scene for this I review two books that seek to advance our understanding of discourse and language analysis in organization studies. Each has its strengths but both are relatively disengaged from the journal literature in the same field. In response to this weakness I will present a brief citation-based analysis of 'discourse analysis' in the management and organization studies field. This analysis brings to light eight different streams of work that are underway. Various forms of language analysis do feature among these. But the most prominent form is concerned with the analysis of knowledge and practice (particularly the distribution and character of various forms of management knowledge). I conclude by arguing that this, rather than forms of language analysis, is the distinctive form of discourse analysis in organization studies. In other words, and following on from the point by Fairclough and his colleagues, the dominant approach to 'discourse' in organization studies takes a distinctive form. There are many examples of this kind of work (see for example Westwood and Clegg, 2003), and among the most cited (see table 2) are those that provide critical analysis of management discourse (Du Gay,1994; Townley, 1993; Kerfoot and Knights, 1998). The approach has some distinctive features including ambivalence over the particular 'media' in which (by which) it is articulated, performed or 
inscribed. 'Discourse' as a concept explores the ordering or organization of speech, meanings and behaviour. It does not simply refer to the social constructivist concern with meaning, but the specific interconnection of texts, meaning and practices. Discourse is, as the noted communication theorist John Fiske wrote (1996:217), as material as a surgeon's knife and the walls of the prison cell. In David Lodge's Campus novel Nice Work' this approach to discourse is neatly presented as an analysis by one of the main characters of her relationship with the other main character (Note: this excerpt contains explicit material that some readers might find uncomfortable. Sensitive readers may wish to move to the next section of the paper).

\section{Doing discourse analysis}

At the centre of Nice Work (Lodge, 1988) is an affair between British factory manager Vic Wilcox and university English lecturer Robyn Penrose. As their relationship develops Robyn introduces Vic to semiotics and discourse analysis. She illustrates the theory with examples that challenge Vic's assumptions about his life and world (sensitive readers might wish to skip this section). At the height of their affair they travel to Frankfurt together. Here Vic declares he is in love with Robyn and she replies:

\footnotetext{
'No, you don't, Vic.'

'I've been in love with you for weeks'.

'There's no such thing', she says. 'It's 'a rhetorical device' and a 'bourgeoisie fantasy'.

'Haven't you ever been in love, then?'

'When I was younger,' she says, 'I allowed myself to be constructed by the discourse of romantic love for a while yes.'

'What the hell does that mean?'

'We aren't essences, Vic. We aren't unique individual essences existing prior to language. There is only language'.

'What about this?' he says, sliding his hand between her legs.

'Language and biology', she says, opening her legs wider.

'Of course we have bodies, physical needs and appetites. My muscles contract when you touch me there - feel?'

'I feel, 'he says.
} 
'And that's nice. But the discourse of romantic love pretends that your finger and my clitoris are extensions of two unique individual selves who need each other and only each other and cannot be happy without each other for ever and ever'. (Lodge, 1988: 293)

Put differently discourse connects certain forms of knowledge and particular practices. Discourse, as a concept brings together the practices of romantic love, the meanings and the texts (spoken and written words).

In some respects Vic and Robyn's relationship is a metaphor for the pleasures and difficulties of this form of discourse analysis. Like many students of business and management, Vic initially finds discourse analysis bewildering. He is defensive and irritated by its bizarre claims. Eventually though he begins to embrace Robyn's body of knowledge (its seems unlikely that he'd have stuck with it without the promise of a return on his affections) and in a kind of genderappropriate reversal of the Pygmalion plot the book ends with Vic reciting Tennyson and challenging Robyn on the slippage between the signifier and signified (1988:362).

Robyn, meanwhile, (like many academics I would suggest) finds some exhilaration and challenge in the confrontation with Vic's world (1988:130). She is shocked and appalled by the conditions and practices of the engineering factory Vic manages; but she also takes some pleasure in putting her theoretical skills to work in more visceral and embodied settings as compared with the books, plays and poems that are her usual targets. As her analysis of romantic love shows discourse involves very real forms of knowledge and practice.

Like Robyn, the two books I review here are passionate about the theories and methodologies they use to unpack business and organizational topics. They also 
share Robyn's pedagogical commitments at bringing discourse analysis to students of business and management (including practicing managers). They are also distinctive in terms of empirical focus and analytical approaches. Renata and John Fox's Organizational Discourse, A Language-Ideology-Power Perspective deals with corporate public relations and takes a form of critical discourse analysis as its method of inquiry. Susanne Tietze, Laurie Cohen and Gill Musson's Understanding Organizations through Language is concerned with 'internal' organizational communication (if I can put it that way) and uses different methods of language analysis (semiotics, narrative, figures of speech and discourse). Both books are student-focused and offer lively and rich discussions of illustrative case materials. Each is thus worth considering as a supportive text for public relations and organizational communication courses. Each book has some internal weaknesses (which I will discuss briefly below), but my general concern with them is their uneven and rather uncomfortable relationships with the journalbased research literature on discourse and language analysis in organization studies. This is not to say that the approaches that each text presents are uninformed or inaccurate, but rather some of the claims made about the journal literature are erroneous - particularly in the Fox and Fox text. Before I discuss this a small qualification is needed.

Organizational discourse, in a broad sense, is a relatively new research field (Alvesson and Karreman, 2000; Ball and Hodgeson, 2001; Chia, 2000; Lok and Willmott, 2006; Grant et al., 2004; Prichard et al, 2004) with a consequent lack of agreement over just what 'discourse' analysis in organizations might be about and how one might go about investigating it. New academic fields are like political movements (Westwood and Clegg, 2003). Just what 'counts' is a result of internal struggles played out through core journals, key conferences, authoritative 
figures, important texts and the institutional support for these provided by universities, states and economies. The result is that what 'counts' as discourse analysis depends a lot on one's academic biography and the particular location in which one works (Prichard et al, 2004; Prichard, 2005). There is no way to resolve these differences, indeed most would agree they are an important part of ensure there the development of the field. One must instead work out how to engage with them. One way is to join a particular faction of the 'movement', so to speak, and promote and defend your 'village's' favoured approach (Hardy and Phillips, 2002; Phillips, 2003). Another way is to identify the diversity of approaches, try to map these out and accept streams of activity as different entry points on a common phenomenon. One way to do this, and certainly not the only way, is to explore citation patterns of works on 'discourse analysis' in organization studies. This is the approach I present below. The analysis highlights the discontinuity between the approaches to 'discourse' the books champion, and those highly supported in the journal literature. This is perhaps inevitable. All books and journal articles are to varying extents efforts to direct, sway or shape a field in a particular direction. One way to strengthen the field as a whole is to recognize the distinctive contribution of a range of approaches as different entry points to a particular field. Before I proceed with this let me now offer some notes on the strengths and weaknesses of each books.

\section{Languaging in organizations}

The text Understanding Organizations Through Language includes four different forms of language analysis: semiotic, metaphorical, narrative and discourse analysis (both genre and knowledge forms are discussed). Each is neatly presented in engaging student focused chapters with illustrative cases and student discussion questions. Usefully the authors also include some of their own 
empirical research as cases. Each chapter on different forms of language analysis works well as a single offering. But as a group, side by side, I found them difficult. There is precious little cross-referencing between them. Consequently, readers may well wonder how, or if, discourses, metaphors, narratives and signs are inter-related? Each perspective is located in the interpretive tradition, but do they 'talk' to each other? Does the syntagmatic character of organizational signs relate to figures of organizational speech? Does Barthes' myth function underpin organizational story telling? Are discourses (i.e forms of knowledge and practice) also narratives? Do they differ or can they be interconnected? Perhaps the authors couldn't agree among themselves on a common approach? The only hint I found of a framework that might relate signs, narratives, metaphors and discourse together is the notion of 'symbolic code' (2003:131).

At the beginning of chapter eight on 'leadership the authors write:

We have seen how the process of encoding and decoding work to generate particular meanings through a variety of symbolic codes, and combinations of codes, including metaphors, storytelling, discourse, culture and gendering through language. (2003:131, my emphasis).

Much more could have been made of the notion of symbolic code to draw together the book as a whole; particularly the first four conceptually orientated chapters and the latter four thematic chapters on culture, gender, leadership and communication technology. Alternatively perhaps the notion of 'semiosis' (Chouliaraki and Fairclough, 1999) might have been helpful to weave the different analytical approaches into a loose interpretive framework ${ }^{2}$.

\footnotetext{
${ }^{2}$ Also the note on page 131 suggests that 'culture' and 'gender' are symbolic codes akin to metaphors, story telling and discourse. This needs to teased out a little more if the book goes to a second edition.
} 
Stepping back a bit, it seems to me that it would be helpful also to begin by clarifying some assumptions about the realities of the world that these interpretive forms were attempting to unravel. We might assume that what we confront in organizations are overdetermined relations between many different meaning making practices. Thus each type of analysis is a different entry point on this inevitably messy world. This relates to what I see as a second weakness with the text.

In Nice Work Robyn, you may recall, takes a seemingly reductionist position with respect to the relation between discourse and the 'world'. All there is is 'language and biology', she claims. Tietze et al share this assumption - to a point. The book begins with:

We see organizations, not as static entities, but as dynamic processes, constructed and reconstructed through activities and practices, being woven in and through language and talk. (2003:10)

Here language and talk are said to weave activities and practices together. But how do we deal with these 'other' practices? Do they shape talk and language at all? What is missing here is some recognition or exploration of the relation been the symbolic or cultural or interpretive, and other dimensions or processes. The four analytical frameworks Tietze et al discuss are different ways of making meaning in organizations. But how is 'meaning-making' interwoven with the practices and activities that organize political or economic relations? In summary the book for me risks undermining its admirable features with a lack of internal connectedness and a lack of discussion of how the analysis of interpretive or symbolic processes they promote bear on and are shaped by political and economic relations in organizations. 


\section{Delving in corporate discourse}

These concerns don't apply to Renata and John Fox's book. Their book assumes some kind of dialectical relations between discursive, political and economic processes and thus the problem (as found in Tietze et al) of the relations between symbolic and non-symbolic (political and economic) processes can be put aside. Also they use one analytical framework directed at one (broad) problem and thus the problem of coherence across the text is not quite so acute. In brief the book explores corporate public discourse via analysis of communication events. The question they ask is how corporations use communication processes to secure consent from stakeholders. The book then offers us an analysis of the ideological processes in which corporations are engaged. Most chapters contribute to this argument by presenting discussions of different communicative events (e.g. CEO interview, media events and websites) although (like the Tietze et al text) the authors struggle in the final four chapters to apply their perspective to generic topics such as gender and globalization without importing still further analytical ideas. The middle section of the book presents an elaborate quantitative analysis of corporate texts. This work could help confirm, via analysis of a wider sample, the finding from close qualitative analysis of key texts but the particular chapters here are strongly methodological and thus are a little out-of-step with the mode of presentation found in the earlier and later chapters. The book makes few concessions to novice learners and is thus more suited to research orientated postgraduates over undergraduate communication or management students. The text in my view has two main weaknesses: poor chapter organization and a penchant for rather grand and vacuous claims about organization studies which, as the citation based analysis below shows, prove to be rather dubious. 
On the first point the book is a maze of chapters of varying lengths. The chapter on the notion of 'management discourse community' is barely two and a $1 / 2$ pages in length. Others, such as the quantitative analysis of corporate communication genres, are closer to 17 pages. The books' editor/s might have been more assertive here and helped the authors combine chapters into more coherent and satisfying segments of text and illustration.

On the second point the book claims to make a contribution to organization studies. While the content of the book may well be such a contribution, the way it attempts to establish this claim is rather questionable. Early in the book the authors' point out that

As regards the status of language in organization studies, little, so it seems, has changed in organization studies since Holden's (1987) survey of mentions of language topics in a corpus of 463 English-language texts on international management, business and marketing. . . When mentioned, language topics were handled with 'perfunctory brevity and frequent ignorance of linguistic fact. (2004:21)

Supporting the claims of a 1987 survey suggests, frankly, that either the authors' don't 'get out much', or their library's subscription to all the major organization studies and management journals ceased somewhere around 1990 (and/or someone forgot to connect them to the internet). Quite simply linguistics related topics, issues, concerns and methodologies have been the consistent (some might say dominant) focus of (particularly European) organization studies since the early 1990s. To demonstrate this, and also to bring to light what I would regard as a map of the field of 'organizational discourse' I now present a brief citation based analysis of the major streams of work. 
Getting with the programme

Both books have some fine qualities. My main issue with them both is that they lack a well grounded connection to the journal research literature in the field. The problem here may well be one of disciplinary background and location. When one reads organization studies from a linguistics background or a location embedded in the humanities one might not see language or discourse analysis at all. The two most cited works in the field that use the notion of 'discourse' are Barley and Kunda's (1992) analysis of $20^{\text {th }}$ Century changes to management knowledge and Du Gay and Salaman's (1992) discourse analysis of the customer service movement in UK businesses. None of these authors are linguists by training and it may be that to linguists the analysis they present is not strongly linguistic in character. Perhaps what we are confronting here is, as Fairclough and his colleagues suggest (Fairclough et al, 2004), the field's distinctive form of discourse analysis that has ambivalent relations with linguistics, formal language analysis and other disciplines.

\section{So just what is going on?}

One way to explore what 'counts' as 'discourse' and 'discourse analysis' is to look to those works cited by others in the field and thus could be said to have the community's support. There are some problems with this approach. We cite each other's published work for various reasons and thus citation rates might not be a particularly strong way to identify a preferred form of discourse analysis. Nevertheless, highly cited works that use the term 'discourse' in an illustrative sense show us the accepted, common or possibly prevailing ways in which the organization studies community has come to know the term 'discourse'. If we map this we might then be able to identify the community's various approaches to discourse. 
If we query ISI's Web of Science database (social science citation index) for articles that use the terms 'discourse', 'organization' and 'management' ${ }^{3}$ (found in the abstract, title or key words) we find 444 papers (to the end of 2005). None were published prior to 1988 . The yearly publication count runs from 3 in 1988 to 71 in 2005 with a relatively smooth increasing number across those years ( see table 1).

\section{Insert Table 1 here}

If we then look at the distribution of these papers across journals the largest numbers are found in European-based management and organization studies journals: Journal of Management Studies, 42, Organization Studies, 37, Organization, 36 and Human Relations, 23. However this is not true of the most highly cited in the list. Six of the 10 most cited papers ${ }^{4}$ in the sample are in US-based journals (ASQ, AMR and Organization Science). This suggests a journal-based effect on the most cited examples in the total number (e.g. certain journals are consistently cited more than other journals).

In order to provide a sketch of the various forms of organizational discourse analysis supported by the broader community via citation, we need to look more closely at these works and thus need a more convenient sample. If we select papers cited more than 16 times, we are left with the 40 most cited papers. I then read these papers and based on this grouped them on the basis of the

\footnotetext{
${ }^{3}$ This includes derivatives such as 'managers', 'organizing' and 'organizations' etc.

4 The 10 most cited articles were: Barley and Kunda (1992), 150 cites; Dugay and Salaman (1992), 107 cites; Jessop (1995), 100 cites; Gefen and Straub (1997), 84 cites; Barry and Elmes (1997), 82 cites; Astley and Zammuto (1992), 75 cites; Davis and Stout (1992), 58 cites; Watson (1995), 64 cites; Townley (1993), 59 cites; Zbaracki (1998), 55 cites)
} 
methodological approach they take with respect to 'discourse'. The groupings are presented in table 2 .

\section{Locate table 2 here}

From this we can note that the largest and most significant group of papers use 'discourse analysis' as a synonym for analysis of forms of knowledge and practice - particularly forms of management knowledge and practice. This group draws primarily, but not exclusively, on Foucault's approach to discourse. Rhetoric, and rhetorical practices forms a second significant focus of highly cited 'discourse analyses'. The remainder of the papers address discourse as narrative, text, language use, and discourse as general or public debate ${ }^{5}$.

So what does this tell us?

The two books reviewed here make useful attempts to present 'discourse' and language analysis' as it relates to the study of organizations. The Foxs' book is premised on the claim that organization studies has change little since 1987 with respect to discourse analysis. The illustrative citation analysis above suggests this is at best misleading. The Tietze et al text is a more reliable source when it comes to the presentation of language and discourse analysis in organization studies. Their book is based around a semiotic or symbolic code approach. It includes 'discourse analyses' as a separate form of analysis and includes both genre analysis and analysis of knowledge and practice (pages 71-90). The Tietze book is then a much better overview of the field if we set it alongside our illustrative

\footnotetext{
${ }^{5}$ This analysis is purely illustrative and highlights a distinction between 'discourse' as forms of knowledge and practice, and discourse as attending to language use in organizations. At the same time each of the groupings we identify are not discrete. In some instances they share concepts and resources and empirical strategies. In short such categorization is loose-fitting and cautious.
} 
citation analysis above. However I would suggest the need to go further. What we find in highly cited journal literature are eight possible entry points for analysis, and one distinctive and currently dominant mode of organizational discourse analysis. This mode uses the notion of 'discourse' in a particular way to unravel the character and distribution of forms of organizational knowledge and practice (texts, meanings and behaviours). The form and character of organizational knowledge and practice is, I would suggest, an important empirical and analytical issue in the field (there are others of course). Perhaps then, a more compelling way to present discourse and/or language analysis as it relates to the study of organizations and organizing is to first sketch out the field's empirical and analytical targets/'problems' (e.g. the distribution and elaboration of management knowledge and practice) and then work through the various modes of analysis. This may well provide a more engaging way of showing students just how 'discourse analysis' helps us understand the problematics of organizing and the strengths and weaknesses of each mode of discourse or language analysis. In other words such books should be more problem-focused and engaged in the current research literature ${ }^{6}$.

\section{References}

Abrahamson, E. (1997). The emergence and prevalence of employee management rhetorics: The effects of long waves, labor unions, and turnover, 1875 to 1992. Academy of Management Journal, 40(3), 491-533.

\footnotetext{
${ }^{6}$ Thanks to MCQ Reviews and Forum Editor Kathleen Krone for help with this summary point.
} 
Abrahamson, E., \& Fairchild, G. (1999). Management fashion: Lifecycles, triggers, and collective learning processes. Administrative Science Quarterly, 44(4), 708-740.

Alvesson, M. (1994). Talking in Organizations - Managing Identity and Impressions in an Advertising Agency. Organization Studies, 15(4), 535563.

Alvesson, M., and Karreman, D. (2000). 'Varieties of discourse: On the study of organizations through discourse analysis'. Human Relations, 53(9):11251149.

Astley, W. G., \& Zammuto, R. F. (1992). Organization Science, Managers, and Language Games. Organization Science, 3(4), 443-460.

Ball, K. and Hodgeson, D. (2001). 'Knowing Your Limits: Organization Studies and Discourse Analytic Technologies'. Paper presented at the Second International Conference on Critical Management Studies, Manchester, England, July

Barley, S. R., \& Kunda, G. (1992). Design and Devotion - Surges of Rational and Normative Ideologies of Control in Managerial Discourse. Administrative Science Quarterly, 37(3), 363-399.

Barry, D., \& Elmes, M. (1997). Strategy retold: Toward a narrative view of strategic discourse. Academy of Management Review, 22(2), 429-452.

Chia, R. (2000). 'Discourse Analysis as Organizational Analysis'. Organization, 7(3): 513-518.

Chouliaraki, L, and N. Fairclough (1999). Discourse in late modernity : rethinking critical discourse analysis, Edinburgh : Edinburgh University Press

Clark, T., \& Salaman, G. (1998). Telling tales: Management gurus' narratives and the construction of managerial identity. Journal of Management Studies, 35(2), 137-161. 
Cooper, D. J., Hinings, B., Greenwood, R., \& Brown, J. L. (1996). Sedimentation and transformation in organizational change: The case of Canadian law firms. Organization Studies, 17(4), 623-647.

Covaleski, M. A., Dirsmith, M. W., Heian, J. B., \& Samuel, S. (1998). The calculated and the avowed: Techniques of discipline and struggles over identity in Big Six public accounting firms. Administrative Science Quarterly, 43(2), 293-327.

Davis, G. F., \& Stout, S. K. (1992). Organization Theory and the Market for Corporate-Control - a Dynamic Analysis of the Characteristics of Large Takeover Targets, 1980-1990. Administrative Science Quarterly, 37(4), 605633.

DeCock, C., \& Hipkin, I. (1997). TQM and BPR: Beyond the beyond myth. Journal of Management Studies, 34(5), 659-675.

Denhardt, R. B., \& Denhardt, J. V. (2000). The New Public Service: Serving rather than steering. Public Administration Review, 60(6), 549-559.

Dugay, P. (1994). Making up Managers - Bureaucracy, Enterprise and the Liberal Art of Separation. British Journal of Sociology, 45(4), 655-674.

Dugay, P., \& Salaman, G. (1992). The Cult Ure of the Customer. Journal of Management Studies, 29(5), 615-633.

duGay, P., Salaman, G., \& Rees, B. (1996). The conduct of management and the management of conduct: Contemporary managerial discourse and the constitution of the 'competent' manager. Journal of Management Studies, 33(3), 263-282.

Fairclough, N, Graham, P, Lemke, J and Wodak, R (2004) Introduction, Critical Discourse Studies, 1(1):1-7.

Fairclough, N (2005) 'Discourse Analysis in Organization Studies: The Case for Critical Realism', Organization Studies, 26(6): 915-939. 
Fairhurst, G. T. and Putnam, L. (2004) 'Organizations as Discursive Constructions', Communication Theory, 14(1):5-26

Fairhurst, G. T. (1993). The Leader-Member Exchange Patterns of Women Leaders in Industry - a Discourse Analysis. Communication Monographs, 60(4), 321-351.

Fiske, J. (1996) 'Opening the Hallway; Some Remarks on the Fertility of Stuart Hall's contribution to Critical Theory', pp.212-220. In Morley, D. and Chen, H. (eds.) Stuart Hall critical dialogues in cultural studies, London: Routledge

Fondas, N. (1997). Feminization unveiled: Management qualities in contemporary writings. Academy of Management Review, 22(1), 257-282.

Fournier, V., \& Grey, C. (1999). Tao much, too little and too often: A critique of du Gay's analysis of enterprise. Organization, 6(1), 107-128.

Gefen, D., \& Straub, D. W. (1997). Gender differences in the perception and use of E-mail: An extension to the technology acceptance model. Mis Quarterly, $21(4), 389-400$.

Gherardi, S. (1999). Learning as problem-driven or learning in the face of mystery? Organization Studies, 20(1), 101-123.

Gill, S. (1992). Economic Globalization and the Internationalization of Authority Limits and Contradictions. Geoforum, 23(3), 269-283.

Grant, D. Keenoy, T and Oswick, C. (1998) 'Introduction: Organizational Discourse: Of Diversity, Dichotomy and Multi-disciplinarity', In Grant, D. Keenoy, T and Oswick C (eds) Discourse and Organization, pp.1-14, London: Sage.

Grant, D., Hardy, C., Oswick, C \& Putnam, L. (eds.). The Sage Handbook of Organizational Discourse. . London: Sage. 
Grint, K., \& Case, P. (1998). The violent rhetoric of re-engineering: Management consultancy on the offensive. Journal of Management Studies, 35(5), 557577.

Gubrium, J. F., \& Holstein, J. A. (1993). Family Discourse, Organizational Embeddedness, and Local Enactment. Journal of Family Issues, 14(1), 66-81.

Hardy, C., \& Phillips, N. (1999). No joking matter: Discursive struggle in the Canadian refugee system. Organization Studies, 20(1), 1-24.

Hatch, M. J. (1997). Irony and the social construction of contradiction in the humor of a management team. Organization Science, 8(3), 275-288.

Heracleous, L., \& Barrett, M. (2001). Organizational change as discourse:

Communicative actions and deep structures in the context of information technology implementation. Academy of Management Journal, 44(4), 755778.

Jessop, B. (1995). The Regulation Approach, Governance and Post-Fordism Alternative Perspectives on Economic and Political-Change. Economy and Society, 24(3), 307-333.

Jewkes, R., Abrahams, N., \& Mvo, Z. (1998). Why do nurses abuse patients? Reflections from South African obstetric services. Social Science \& Medicine, 47(11), 1781-1795.

Kerfoot, D., \& Knights, D. (1993). Management, Masculinity and Manipulation from Paternalism to Corporate-Strategy in Financial Services in Britain. Journal of Management Studies, 30(4), 659-677.

Knights, D., \& Morgan, G. (1995). Strategy under the Microscope - Strategic Management and It in Financial Services. Journal of Management Studies, $32(2), 191-214$.

Lodge, D (1988) Nice Work, London: Penguin 
Lok, J and Willmott, H (2006) 'Institutional Theory, Language and Discourse Analysis: A Comment on Phillips, Lawrence and Hardy', Academy of Management Review, 31(2):477-488

Newton, T. (1998). Theorizing subjectivity in organizations: The failure of Foucauldian studies? Organization Studies, 19(3), 415-447.

O'Neill, P., \& Gibson-Graham, J. K. (1999). Enterprise discourse and executive talk: stories that destabilize the company. Transactions of the Institute of British Geographers, 24(1), 11-22.

Palmer, I., \& Dunford, R. (1996). Conflicting uses of metaphors: Reconceptualizing their use in the field of organizational change. Academy of Management Review, $21(3), 691-717$.

Phillips, N. (2003). 'Discourse or Institution? Institutional Theory and the Challenge of Critical Discourse Analysis', in Westwood R and Clegg S R eds. Debating Organization: Point/Counterpoint, pp. 220-231. Malden, MA: Blackwell Publishing.

Phillips, N., \& Hardy, C. (1997). Managing multiple identities: Discourse, legitimacy and resources in the UK refugee system. Organization, 4(2), 159-185.

Phillips, N., \& Hardy, C. (2002). Discourse Analysis: Investigating Processes of Social Construction (Vol. 50). Thousand Oaks, California: Sage.

Prichard, C (2005) 'Challenging academic imperialism: Some tactics for constructing an organizational communication of the elsewhere', Management Communication Quarterly 19(2):1-9.

Prichard, C., Jones, D. \& Stablein, R. (2004). Doing discourse analysis in organization studies, in Grant, D., Hardy, C., Oswick, C \& Putnam, L. (eds.). The Sage Handbook of Organizational Discourse. (pp.213-236). London: Sage. 
Sturdy, A. (1998). Customer care in a consumer society: Smiling and sometimes meaning it? Organization, 5(1), 27-53.

Townley, B. (1993). Foucault, Power Knowledge, and Its Relevance for HumanResource Management. Academy of Management Review, 18(3), 518-545.

Tsoukas, H. (1992). Panoptic Reason and the Search for Totality - a CriticalAssessment of the Critical Systems Perspective. Human Relations, 45(7), 637-657.

Watson, T. J. (1995). Rhetoric, Discourse and Argument in Organizational Sense Making - a Reflexive Tale. Organization Studies, 16(5), 805-821.

Westwood, B. and Clegg, S. (2003) 'The discourse of organization studies: dissensus, politics and paradigms', In B. Westwood and S. Clegg (eds.), Debating Organization : Point-counterpoint in Organization Studies, Malden, MA : Blackwell Publishing

Zajac, E. J., \& Westphal, J. D. (1994). The Costs and Benefits of Managerial Incentives and Monitoring in Large Us Corporations - When Is More Not Better. Strategic Management Journal, 15, 121-142.

Zbaracki, M. J. (1998). The rhetoric and reality of total quality management. Administrative Science Quarterly, 43(3), 602-636. 


$\begin{array}{crrl} & 1988 & 3 & \\ 1992 & 10 & \\ 1993 & 5 & \\ 1994 & 11 & \\ 1995 & 14 & \\ 1996 & 22 & \\ 1997 & 22 & \\ 1998 & 24 & \\ 1999 & 27 & \\ 2000 & 38 & \\ 2001 & 28 & \text { Table 1. Discourse } \\ 2002 & 48 & \text { papers published } \\ & 52 & \text { 1988-2005. (Source: } \\ & 2003 & 61 & \text { ISI Web of Science) } \\ & 2004 & 79 & \\ \text { Total } & 444 & \end{array}$


Table 2. Groupings of $\mathbf{4 0}$ most cited 'Discourse/Management/Organization' papers (Source: ISI Web of Science)

\begin{tabular}{|c|c|}
\hline $\begin{array}{l}\text { Structurationist approach } \\
\text { (rhetoric and structures) }\end{array}$ & Heracleous \& Hendry, 2000 (Papers: 1, Cites: 18) \\
\hline Texts and discursive processes & $\begin{array}{l}\text { Hardy \& Phillips, } 1999 \text { (25); Phillips \& Hardy, } 1997 \text { (27) ( Total } \\
\text { papers :2, Total Cites: 52) }\end{array}$ \\
\hline $\begin{array}{l}\text { Language games and discourse } \\
\text { communities }\end{array}$ & $\begin{array}{l}\text { Astley \& Zammuto, } 1992 \text { (75); Denhardt, } 2000 \text { (18); Gubrium and } \\
\text { Holstein, 1993(17); Tsoukas, } 1992 \text { (18) (Total:4, total cites:128) }\end{array}$ \\
\hline Narrative/s & $\begin{array}{l}\text { Barry \& Elmes, } 1997 \text { (82); Clark \& Salaman, } 1998 \text { (21); O'Neill \& } \\
\text { Gibson-Graham, } 1999 \text { (27) (Total Papers: } 3 \text { Total Cites: 130) }\end{array}$ \\
\hline $\begin{array}{l}\text { Language use, communication, } \\
\text { talk, rhetoric and texts (literary } \\
\text { analysis) }\end{array}$ & $\begin{array}{l}\text { Alvesson, } 1994 \text { (23); Fairhurst, } 1993 \text { (28); Fondas, 1997(36); } \\
\text { Gefen \& Straub, } 1997 \text { (84); Hatch, } 1997 \text { (26); Palmer \& Dunford, } \\
1996 \text { (26) ( Total papers 6, Total Cites: 223) }\end{array}$ \\
\hline $\begin{array}{l}\text { Public debate } \quad \text { (general } \\
\text { discourse) }\end{array}$ & $\begin{array}{l}\text { Cooper, Hinings, Greenwood, \& Brown, } 1996 \text { (35); Davis \& Stout, } \\
1992(64) ; \text { Gill, 1992(22); Zajac \& Westphal, } 1994 \text { (40); Jessop, } \\
1995 \text { (100) (Total papers: 5, Total Cites:261) }\end{array}$ \\
\hline Rhetorical forms of knowledge & $\begin{array}{l}\text { Abrahamson, 1997(41); Abrahamson \& Fairchild, } 1999 \text { (49); } \\
\text { Barley \& Kunda, 1992 (150); Grint \& Case, } 1998 \text { (18); Watson, } \\
\text { 1995(64); Zbaracki, } 1998 \text { (55) (Total papers:6, Total Cites:377) }\end{array}$ \\
\hline Knowledge and practice & $\begin{array}{l}\text { Covaleski, Dirsmith, Heian, \& Samuel, } 1998 \text { (39); DeCock \& } \\
\text { Hipkin, } 1997 \text { (20); Dugay, } 1994 \text { (27); Dugay \& Salaman, 1992 } \\
\text { (107); DuGay, Salaman, \& Rees, 1996 (40); Fondas, 1997 (36); } \\
\text { Fournier \& Grey, } 1999 \text { (23); Gherardi, 1999 (25); Jewkes, } \\
\text { Abrahams, \& Mvo, } 1998 \text { (34); Kerfoot \& Knights, 1993 (51); } \\
\text { Knights \& Morgan, 1995 (18); Newton, 1998 (33); Sturdy, } 1998 \\
\text { (19); Townley, 1993 (14) (Total papers: 14, Total Cites 386): }\end{array}$ \\
\hline
\end{tabular}




\title{
The organization of organizational discourse
}

\author{
Prichard, Craig
}

2007-12-19T00:15:30Z

http://hdl.handle.net/10179/528

22/04/2023 - Downloaded from MASSEY RESEARCH ONLINE 